мобильности специалистов технического профиля средствами иностранного языка: дис. ... д-ра. пед. наук: 13.00.08 / Л. П. Меркулова. - Самара, 2008. - 454 с. 9. Мясищев В. Н. Проблема отношений человека и eе место в психологии / В. Н. Мясищев // Вопросы психологии. - 1967. - № 5. - С. 142-154. 10. Игошев Б. М. Системно-интегративная организация подготовки профессионально мобильных педагогов: дис. ... д-ра. пед. наук: 13.00.08 / Б. М. Игошев. - М., 2008. - 394 с. 11. Дубовицкая Т. Д. Гуманистическая теория и практика образования / Т. Д. Дубовицкая // Педагогическая наука и ее методология в контексте современности: сб. науч. ст. - М., 2001. - С. 281-286.

\title{
ФОРМУВАННЯ МОВНОЇ КОМПЕТЕНТНОСТІ МАЙБУТНІХ УЧИТЕЛІВ ПОЧАТКОВИХ КЛАСІВ У ВНЗ І-І РІВНЯ АКРЕДИТАЦЇ У ПРОЦЕСІ ФАХОВОЇ ПІДГОТОВКИ
}

Шаранда В. С. Формування мовної компетентності майбутніх учителів початкових класів у ВНЗ І-ІІ рівня акредитації у процесі фахової підготовки.

Статтю присвячено дослідженню педагогічних засад формування мовної компетентності майбутніх учителів початкових класів у ВНЗ I-II рівнів акредитації у процесі фахової підготовки. Авторка аналізує теоретичні основи формування, рівні розвитку і зміст мовної компетентності майбутніх учителів, а також представляє методику формування мовної компетентності майбутніх учителів початкових класів у процесі фахової підготовки.

Ключові слова: мовна компетентність, майбутні вчителі, фахова підготовка, педагогічні засади.

Шаранда В. Е. Формирование языковой компетентности будущих учителей начальных классов в ВУЗе I-II уровня аккредитации в процессе профессиональной подготовки.

Статья посвящена исследованию педагогических основ формирования языковой компетентности будущих учителей начальных классов в вузах I-II уровней аккредитации в процессе профессиональной подготовки. Автор анализирует теоретические основы формирования, уровни развития и содержание языковой компетентности будущих учителей, а также представляет методику формирования языковой компетентности будущих учителей начальных классов в процессе профессиональной подготовки.

Ключевые слова: языковая компетентность, будущие учителя, профессиональная подготовка, педагогические основы.

Sharanda V. Ye. Forming primary school teachers' linguistic competence at higher schools of the first and second level of accreditation in the process of professional training.

The article is devoted to the pedagogical fundamentals of forming primary school teachers' linguistic competence at higher schools of the first and second level of accreditation in the process of professional training. The author analyzes the concept of linguistic competence, the theoretical fundamentals of its formation, and the levels of its development. The author also presents the technique of forming primary school teachers' linguistic competence in the process of professional training.

Key words: linguistic competence, future teachers, professional training, pedagogical fundamentals. 
Державне будівництво в Україні, національне відродження неможливі без розвитку володіння українською мовою, яка Конституцією України утверджена як державна і є засобом міжнаціонального спілкування. Ось чому державною політикою у сфері вищої освіти виокремлене питання про вивчення української мови у вищих навчальних закладах як одне 3 найважливіших.

Теоретичною основою дослідження стали праці психологів та психолінгвістів про мовленнєву діяльність та механізми мовлення (Л. Виготський, І. Зимня, О. Леонтьєв, Л. Щерба), провідні ідеї дидактів щодо комунікативно-діяльнісного підходу до навчання мови (О. Біляєв, М. Вашуленко, І. Гудзик, О. Дудников, В. Мельничайко та ін.) та лінгвістів 3 питань функціонування морфологічних категорій (О. Безпояско, О. Бондарко, М. Жовтобрюх, А. Загнітко, В. Русанівський та ін.), досягнення в галузі функціональної практичної стилістики (А. Коваль, М. Кожина, Л. Мацько, М. Пентилюк, М. Стельмахович та ін.), дидактичні положення щодо організації навчального процесу у вищій школі (А. Алексюк, С. Архангельський, Ю. Бабанський, В. Вергасов та ін.).

Завданням вищої школи України є не лише підготовка спеціалістів відповідного профілю, а й формування особистості громадянина, свідомого учасника державотворчих процесів. Національна свідомість українського народу, його відданість українській ідеї була й залишається важливим фактором відродження й розбудови української держави. Відповідно до цього навчально-виховний процес у вищих закладах повинен бути спрямований на пізнання своїх коренів, історії, мови, традицій, культури, що сприятиме передусім формуванню вмінь українського мовлення на засадах громадянської свідомості й активності.

Mema cmammi: визначити й обгрунтувати педагогічні умови формування мовної компетентності майбутніх учителів початкових класів у ВНЗ I-II рівнів акредитації у процесі фахової підготовки.

Відповідно до мети дослідження визначено основні завдання:

- дослідити теоретичні основи формування мовної компетентності та розкрити ії зміст;

- проаналізувати рівень сформованості мовної компетентності майбутніх учителів початкових класів у процесі фахової підготовки;

- охарактеризувати навчальний заклад як об'єкт та базу дослідження;

- визначити й обгрунтувати педагогічні умови формування мовної компетентності та розробити методику формування мовної компетентності майбутніх учителів початкових класів у процесі фахової підготовки.

Об'єкт дослідження - фахова підготовка майбутніх учителів початкових класів у ВНЗ I-II рівнів акредитації.

Предмет дослідження - педагогічні умови формування мовної компетентності майбутніх вчителів початкових класів у ВНЗ І-II рівнів акредитації в процесі фахової підготовки.

У дослідженні використовувалися такі методи: а) теоретичні: аналіз психологопедагогічної, науково-методичної, лінгвістичної літератури 3 проблематики досліджуваної теми; встановлення рівнів і розроблення критеріїв сформованості мовної і мовленнєвої компетенції; б) емпіричні: анкетування; тестування; аналіз навчально-методичної документації.

Практичне значення дослідження полягає в тому, що розроблена методика організації роботи творчої групи, спрямованої на формування мовної компетентності майбутніх педагогів. 
Наприкінці XX ст. почали відбуватися докорінні зміни в парадигмі й методології освіти. Стара парадигма, що відображала інтереси і сутність індустріального суспільства, детермінованого пізнання й однозначності оцінок, поступово замінюється методологією інформаційного суспільства, плюралістичного пізнання та ймовірнісної оцінки.

Знання, вміння та навички, що їх молодь нині набуває та виробляє у процесі навчання, є дуже важливими. Водночас актуальним стає поняття компетентності майбутнього фахівця, що, на думку багатьох зарубіжних експертів, визначається багатьма чинниками.

Поняття «компетентнісна освіта» виникло у США в процесі вивчення досвіду роботи видатних учителів. Нині, незважаючи на деякі розбіжності в підходах, фахівці визначають три основних компоненти в компетентнісній освіті: формування знань, умінь і цінностей особистості.

Діяльність людини, зокрема засвоєння будь-яких знань, умінь i навичок, складається 3 конкретних дій, що виконуються людиною. Якщо сфера життя, у якій людина відчуває себе здатною до ефективного функціонування (тобто компетентною) $є$ достатньо широкою, йдеться про так звані ключові, чи життєві компетентності. Якщо ж компетентність поширюється на вужчу сферу, наприклад, у межах певної наукової дисципліни, то можна говорити про предметну чи галузеву компетентність.

Отже, під компетентністю людини педагоги розуміють у певний спосіб структуровані (організовані) набори знань, умінь, навичок i стосунків, які набуваються у процесі навчання.

Нині готовність українських педагогів до впровадження компетентнісного підходу в систему освіти є не тільки декларованою, а й реальною.

Більшість українських педагогів погодилася 3 тлумаченням основних понять компетентнісного підходу. Під поняттям «компетентнісний підхід» розуміють спрямованість освітнього процесу на формування і розвиток ключових і предметних компетентностей особистості. Результатом такого процесу буде формування загальної компетентності людини, що є сукупністю ключових компетентностей, інтегрованою характеристикою особистості. Така характеристика має бути сформована у процесі навчання і містити знання, вміння, досвід діяльності й поведінкові моделі особистості.

Компетентнісний підхід $є$ ключовим методологічним інструментом реалізації цілей Болонського процесу та за своєю сутністю є студентоцентровим.

Одним із шляхів визначення змісту освіти й узгодження його 3 сучасними потребами, інтеграцією до європейського та світового освітніх просторів є орієнтація навчальних програм на набуття ключових компетентностей та на створення ефективних механізмів їх запровадження.

Аналіз науково-теоретичної літератури дає можливість зробити висновки.

Під поняттям «компетентнісний підхід» розуміють спрямованість освітнього процесу на формування $\mathrm{i}$ розвиток ключових i предметних компетентностей особистості.

Компетентнісний підхід в освіті пов'язаний з особистісно зорієнтованим та діяльнісним підходами до навчання оскільки стосується особистості учня.

Найголовніша специфіка компетентнісного підходу полягає в тому, що засвоюються не «готові знання», що передає викладач, а прослідковуються умови походження цього знання. Б. Ельконін наголошує на тому, що конкретних знань 3 певної спеціальності нині недостатньо, i вони виконують підпорядковану роль $[4$, с. 15$]$. 
Компетентнісний підхід є основою кардинальних змін, орієнтирів та завдань сучасної системи вищої освіти. У ньому відображається зміст освіти, який не грунтується на компоненті ЗУН (знань, умінь та навичок), а передбачає виконання важливих ключових функцій, які стосуються різних сфер.

Будь-яка професійна діяльність потребує певних мовнокомунікативних умінь. Професійні мовнокомунікативні вміння особистості визначають іiі мовленнєву поведінку. Професійна комунікативна компетенція передбачає насамперед наявність професійних знань, а також загальної гуманітарної культури людини, іiї вміння орієнтуватися в навколишньому світі, вмінь і навичок спілкування. Тобто вона формується на основі комунікативної компетенції.

Комунікативна компетентність - сукупність знань про спілкування в різноманітних умовах і з різними комунікантами, а також уміння їх ефективного застосування в конкретному спілкуванні в ролі адресанта і адресата.

Комунікативна компетентність визначається комунікативними інтенціями (комунікативними намірами адресата); дотриманням комунікативних стратегій, що дають змогу досягти необхідного результату комунікації; знанням особистості співбесідника; зворотним зв'язком в комунікації, що передбачає врахування психологічних особливостей адресата, його соціальних ролей; умінням долати психологічні «фільтри», розбивати психологічні «щити»; умінням володіти навичками декодування «мови тіла» співбесідника; чіткою орієнтацією і підтриманням самого процесу спілкування; контролем власної мовленнєвої поведінки.

Важливим складником комунікативної компетентності є мовна компетентність, яка визначається як знання учасниками комунікації норм i правил сучасної літературної мови і вміле використання їх у продукуванні висловлювань.

Мовна компетентність передбачає наявність мовленнєвих умінь, що визначають мовленнєву поведінку. Мовленнєві вміння охоплюють уміння говорити, слухати, читати і писати.

Важливим чинником, що впливає на становлення і розвиток професійної мовної компетентності та сприяє самореалізації фахівця, $€$ креативність особистості. Креативні якості індивіда стійкі і забезпечують творчий стиль його мовленнєвої поведінки, продуктивність та унікальність способів і результатів діяльності, а також готовність до творчих конструктивних перетворень у різних сферах життєдіяльності. Ці якості формуються у процесі всього розвитку особистості шляхом неперервного вдосконалення творчих навичок.

Отже, формування комунікативної компетентності передбачає:

- глибокі професійні знання й оволодіння понятійно-категоріальним апаратом певної професійної сфери та відповідною системою термінів;

- досконале володіння сучасною українською літературною мовою;

- уміле професійне використання мовних стилів і жанрів відповідно до місця, часу, обставин, статусно-рольових характеристик партнера;

- знання етикетних мовних формул і вміння ними користуватися;

- уміння працювати з різними типами текстів;

- орієнтування в потоці різнотемної та різнотипної інформації українською мовою на різних каналах їх передавання;

- уміння знаходити, вибирати, сприймати, аналізувати та використовувати інформацію профільного спрямування;

- володіння інтерактивним спілкуванням, характерною ознакою якого $є$ необхідність миттєвої відповідної реакції на повідомлення чи інформацію; 
- уміння оцінювати комунікативну ситуацію швидко i на високому професійному рівні приймати рішення та планувати комунікативні дії.

Професійна мовна компетентність особистості $\epsilon$ показником сформованості системи професійних знань, комунікативних умінь і навичок, ціннісних орієнтацій, загальної гуманітарної культури, інтегральних показників культури мовлення, нсобхідних для якісної професійної діяльності.

Проблема формування мовної компетентності майбутніх педагогів не вичерпується результатом виконаної роботи. дослідження сприятиме розв'язанню проблеми наступності у формуванні мовленнєвих умінь і навичок між школою та вищим навчальним закладом в умовах відсутності україномовного середовища; подальшого вдосконалення різних видів мовленнєвої діяльності студентів під час вивчення українською мовою інших дисциплін.

\section{Література}

1. Байденко В. М. Концептуальная модель государственных образовательных компетентностей / В. М. Байденко. - М. : Просвещение, 2004. - 85 с. 2. Богуш А. М. Мовленнєва компетенція дошкільника як лінгводидактична проблема / А. М. Богуш, П. І. Білоусенко, І. Григоренко // Розвиток творчих здібностей дітей засобами мовлення: збірник наукових праць. - К., Запоріжжя, 1998. - С. 5-15. 3. Гез Н. И. Формирование коммуникативной компетенции как объекта зарубежных методических исследований / Н. И. Гез // Иностранные языки в школе. - 2001. № 2. - С. 17-24. 4. Эльконин Б. Д. Понятие компетентности с позиции развивающего обучения / Б. Д. Эльконин // Современные подходы к компетентностноориентированному образованию. - Красноярск, 2002. - 102 с. 5. Лозова В. І. Формування педагогічної компетентності викладачів вищих навчальних закладів/ В. І. Лозова // Педагогічна підготовка викладачів вищих навчальних закладів: Матеріали міжвуз. наук.-практ. конфер. - Харків : ОВС, 2002. - С. 38. б. Овчарук О. Компетентності як ключ до оновлення змісту освіти / О. Овчарук// Стратегія реформування освіти в Україні. - К., 2003. - 115 с.

УДК 37.037

Вікторія Яковлева

\section{ЯКІСНА ОСВІТА ЯК ПОКАЗНИК СТАНУ ГОТОВНОСТІ ПЕДАГОГІВ ДО ФОРМУВАННЯ ЖИТТЕВОЇ КОМПЕТЕНТНОСТІ УЧНІВ}

Яковлєва В. А. Якісна освіта як показник стану готовності педагогів до формування життєвої компетентності учнів

У статті визначені причини не сформованості життєвої компетентності учнів, проаналізовано рівень готовності випускників педагогічних ВН3 до вирішення професійних завдань (зокрема, формування життєвої компетентності учнів), теоретично обгрунтувано зміст поняття «готовність педагога щодо формування життєвої компетентності учнів».

Ключові слова: освіта, якість освіти, життєва компетентність, готовність до професійної діяльності.

Яковлева В. А. Качественное образование как показатель состояния готовности педагогов к формированию жизненной компетентности учащихся.

В статье определены причины не сформированности жизненной компетентности учащихся, проанализирован уровень готовности выпускников педагогических вузов к решению профессиональных задач (в частности, формирование жизненной 